\title{
Potential Dermal Exposure Assessment of Farmers to Herbicide Imazapic in an Agriculture Area
}

\author{
Anis Zakiah Mazlan'1, Hazilia Hussain'1, \\ Mohamed Azwan Mohamed Zawawi² \\ 1 Department of Environmental Health and Safety, Faculty of Health Sciences. \\ Universiti Teknologi MARA, Bandar Puncak Alam 42300, Malaysia \\ 2 Department of Biological and Agricultural Engineering, Faculty of Engineering, University Putra Malaysia, \\ Serdang 43400, Malaysia
}

aniszakiah89@yahhoo.com, hazilia@salam.uitm.edu.my, azwan@eng.upm.edu.my

\begin{abstract}
For decades, the percentage of pesticide usage has steadily increased in order to meet the demands of food production. The aim of this study is to estimate the risk posed towards farmers through exposure to surface water containing imazapic herbicide using dermal exposure assessment (DEA). For this purpose, hazard index $(\mathrm{HI})$ value was calculated to estimate the risk posed towards the farmers. Although calculated $\mathrm{HI}$ showed a minimum level of risk, there are concerns toward the danger of longterm exposure to the farmers of an agricultural system that could affect their quality of life. Keywords: Dermal exposure assessment; farmers; imazapic; hazard index

eISSN 2398-4279 @ 2018. The Authors. Published for AMER ABRA cE-Bs by e-International Publishing House, Ltd., UK. This is an open access article under the CC BY-NC-ND license (http://creativecommons.org/licenses/bync-nd/4.0/). Peer-review under responsibility of AMER (Association of Malaysian Environment-Behaviour Researchers), ABRA (Association of Behavioural Researchers on Asians) and CE-Bs (Centre for EnvironmentBehaviour Studies), Faculty of Architecture, Planning \& Surveying, Universiti Teknologi MARA, Malaysia. https://doi.org/10.21834/ajqol.v3i11.127
\end{abstract}




\subsection{Introduction}

For decades, the pattern of pesticide usage in agriculture industry has steadily increased both globally and simultaneously with the rise of population growth to meet the demands of food production (Caldas et al., 2011). Almost 30\% global pesticide are from developing countries (Caldas et al., 2011) with Malaysia alone consuming more than 200000 tons pesticide annually comprising of more than 50000 tons of active compounds (Sabere et al., 2013). Pesticides are also classified into different classes depending on its purpose or target organism, and this includes herbicide, insecticide, fungicide, nematicide, and bactericide (Mohd Fuad et al., 2012). The type of pesticide used most in the agricultural practices are herbicides due to its efficiency in killing crop competing weeds without much effort from farm laborers as well as increasing the crop's yield (Colborn \& Short, 1999). However, besides being a favored nacessity in agriculture, herbicides, which are currently being distributed under various trade names are also said to post the most threat to human and environment (Ali et al., 2013).

As a developing country with a host of natural resources available, Malaysia has encouraged its agricultural industry to be one of the main sources of income to bolster the country's economic growth, where various efforts are made by both the government as well as agricultural practitioner in order to improve the quality of their livelihood (Ali et al., 2013; Yacob et al., 2012). In an agricultural area in Tanjung Karang, a new paddy strain was introduced by MARDI; the MR220 CL1 and CL2. Both these strain were introduced to prevent weedy rice problem that required farmers to apply herbicides containing the imazapic compound. Briefly, imazapic is a compound that belongs to the imidazolinone family. It is one of the well-known herbicide used by farmers to kill weedy rice in paddy fields, and it has been introduced in Malaysia for approximately three years prior to this research (Baumart and Santos, 2011; Azmi et al., 2012). However, imazapic potentially being persistent in water for up to 39 days and previous toxicological studies had shown that it can lead to several health effects such as eye irritation, anemia, liver damage, increased cholesterol and muscle degeneration. Hence, this is a major concern that may affect the quality of life of farmers (Cox, 2003). In fact, a study by Mohd Fuad et al., (2012) had recorded several cases of pesticide poisoning and death in Tanjung Karang area (Table 1).

Table 1: Farmers' reported cases and death in relation to pesticide poisoning in the study area (20052010)*

\begin{tabular}{|c|c|c|}
\hline Year & Total case & Total death \\
\hline 2005 & 17 & 2 \\
\hline 2006 & 19 & 1 \\
\hline 2007 & 9 & 3 \\
\hline 2008 & 17 & 3 \\
\hline 2009 & 24 & 2 \\
\hline 2010 & 8 & 3 \\
\hline Total & 94 & 14 \\
\hline
\end{tabular}

*Source: District Hospital Tanjung Karang (2005-2010) as cited in Mohd Fuad et al. (2012).

In relation to the direct exposure of these herbicides, the farmers may also be exposed via body absorption of the herbicide from their daily activities in the field. Eventually, this may 
lead to undesirable health effects to the farmers. Therefore, the aim of this study is to determine the presence of imazapic in the paddy area and to estimate the potential risk towards farmers that exposed to imazapic through surface water contact using dermal exposure assessment (DEA).

\subsection{Methodology \\ Study Area}

This study was carried out at Tanjung Karang Rice Irrigation area, located at 3025' - 3045' N latitude and $100^{\circ} 58^{\prime}-101015^{\prime} \mathrm{E}$ longitude in the state of Selangor. Rice is grown twice a year mainly from December to April and July to November. Kampung Sawah Sempadan compartment consist of 1468 lots with the total area about 2,300 hectares, divided into 24 (Toriman et al., 2014). Block C of Sawah Sempadan was chosen as the specific study area that located at 3027'44.02" - 3028'36.57" N latitude and 101013'00.97" - 101013'41.68" E longitude (Figure 1, a).

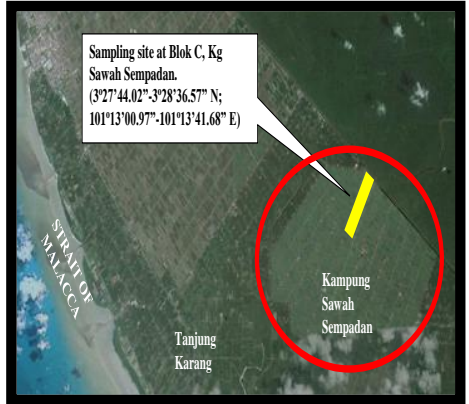

(a)

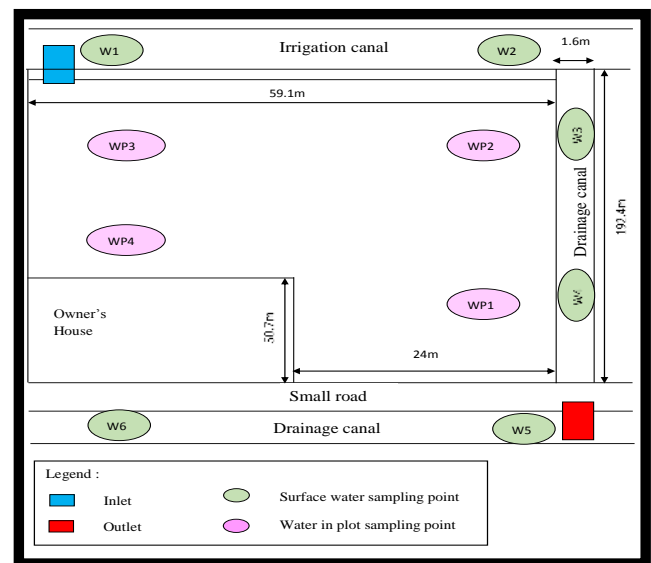

(b)

Figure 1: a) Location of the study area at Kampung Sawah Sempadan*; b) Sampling point for surface water sampling. *(Source: Google Earth, 2015).

\section{Surface Water Sampling}

For surface water sampling, water samples were taken at ten sampling points to obtain the mean concentration of imazapic in the surface water area (Figure 1, b). Surface water samples were collected during two different seasons. The first sampling was carried out in July and August 2013 (wet season) while the second sampling was done in January and February 2014 (dry season). $1 \mathrm{~L}$ sample was collected at each sampling point. The water samples were taken starting from the day before the rice cultivation ( 0 days) and on the 1 st, $3^{\text {rd }}, 5^{\text {th }}, 7^{\text {th }}, 11^{\text {th }}$, and $15^{\text {th }}$ day of imazapic application in the paddy area. Samples were then analyzed using High-Performance Liquid Chromatography-UV (HPLC-UV) after undergoing 
extraction procedure using solid-phase extraction (SPE) method (Mazlan et al., 2015).

\section{Survey}

As for DEA, questionnaires were distributed among 40 farmers who voluntarily participated in the survey. However, only 37 responses using imazapic were taken into account for the DEA calculation. This survey was carried out door-to-door from January 2014 until February 2014.

\section{Dermal Exposure Assessment}

Through questionnaire and water sample analysis, dermal absorbed dose (DAD) value was obtained after which the hazard quotient $(\mathrm{HQ})$ was calculated. To indicate risk, $\mathrm{HQ}$ would have to be more than one $(H Q>1)$. DEA was done based on exposure of farmers through certain body surfaces; which are arms, hands, legs and feet (USEPA, 2011).

$$
\mathrm{DAD}=\underline{\mathrm{DA}} \underline{\underline{\text { event }}} \underline{\mathrm{EV} \times \mathrm{ED} \times \mathrm{EF} \times \mathrm{SA}}
$$

$$
\text { BW x AT }
$$

Based on the formula above, where DAD is dermal absorbed dose ( $\mathrm{mg} / \mathrm{kg}$-day), DAevent represents the absorbed dose per event (mg/ $\mathrm{cm}^{2}$-event), SA is surface area available contact $\left(\mathrm{cm}^{2}\right), E V$ as event frequency (events/day), EF as exposure frequency (days/year), and ED as the exposure duration (years). Additionally, BW represented body weight $(\mathrm{kg})$, and AT as the averaging time (days) where for non-carcinogenic effects AT value is equal to the ED $x$ 365 days/year. For carcinogenic effects, AT is stated as 70 years $\times 365$ days/year. As for absorbed dose per event, it was calculated using the equation (USEPA, 2004).

$$
\mathrm{DA}_{\text {event }}=\mathrm{K}_{\mathrm{p}} \times \mathrm{C}_{\mathrm{w}} \times \mathrm{t}_{\text {event }}
$$

Equation 2 represent the DAevent where it is the absorbed dose per event ( $\mathrm{mg} / \mathrm{cm}^{2}$-event), $\mathrm{K}_{\mathrm{p}}$ is interpreted as the dermal permeability coefficient of compound in water (cm/hour), $\mathrm{C}_{w}$ is related to chemical concentration in water $\left(\mathrm{mg} / \mathrm{cm}^{3}\right)$ while tevent is the event duration (hour/event) that was gathered through questionnaire. After DAD value had been obtained, it was used to calculate $\mathrm{HQ}$ by dividing the DAD value with reference dose value (USEPA, 2004) (Eq. 3). For the absorption of this chemical compound through different body encounter, $H Q$ values were combined to form Hazard Index $(\mathrm{HI})$, with the assumption that the effects of different route of entry for imazapic compound and effects could be additive. Thus, this formula was used to estimate the volume possessed by the entry of imazapic compound through several parts of the body (Pan and Siriwong, 2010)

$$
\begin{aligned}
& \text { Hazard quotient }(\mathrm{HQ})=\mathrm{DAD} / \mathrm{RfD}_{\mathrm{ABS}} \\
& \text { Hazard index }(\mathrm{HI})=\Sigma \mathrm{HQ}_{\text {Arms, Hands, Legs, Feet }}
\end{aligned}
$$


Where it was stated that $\mathrm{HI}$ value that exceeds one would most probably indicate risk towards the target organ of related compound vice versa.

\subsection{Findings and Discussions}

\section{Imazapic in Surface Water}

Table 2: Presence of imazapic concentration in surface water samples during off and main season.

\begin{tabular}{llccl}
\hline Sampling point & $\begin{array}{l}\text { Mean }(\mathrm{ug} / \mathrm{ml}) \\
( \pm \mathrm{SD})\end{array}$ & $\mathrm{df}(\mathbf{9 5 \%} \mathrm{Cl})$ & $\boldsymbol{p}$-value & $\begin{array}{l}\text { Total mean } \\
\text { (ug/ml) }\end{array}$ \\
\hline Off Season & $0.57( \pm 0.26)$ & $38(-0.39,0.11)$ & 0.25 & 1.787 \\
Main Season & $0.71( \pm 0.49)$ & & & \\
\hline & & ${ }^{*} p$-value $<0.05$ &
\end{tabular}

Based on the analysis of the water samples carried out, the result showed no significant mean difference for the comparison of imazapic residue concentration in surface water samples during off and main season ( $p$-value $=0.25, \mathrm{Cl}=-0.39,0.11$ ) (Table 2). However, the mean value recorded for the off season was found to be lower than the mean of the main season at $0.57 \mathrm{ug} / \mathrm{mL}$ and $0.71 \mathrm{ug} / \mathrm{mL}$ respectively. This is probably caused by the rain distribution during off season that was lower than the recorded rain distribution data during main season causing the high level of imazapic residues in surface water. In a study by Zainudin (2010), water quality condition could be weather dependent given that it has a potential source of pollution due to the availability of land use activities. This is because most of the water quality during dry season would stay equally perpetual with some variations in readings (given that they are no severe exterior disruptions or draught) while during the wet season where the rainfall distribution is maximum, the quality of water in that particular area would potentially become either better or worse depending on the source of pollution existed.

\section{Socio-demographic Distribution of Respondents}

Table 3 showed characteristics of the 40 respondents surveyed in this study. The result indicates that $20 \%$ of respondents are aged below 40 years old, $17.5 \%$ aged between 41 to $50,30 \%$ respondents for aged between 51 to 60 , another $30 \%$ for age group 61 to 70 and finally $2.5 \%$ represents above 70 . Additionally, this study found that the number of male respondents at 35 persons (87.5\%) are higher than the female respondents of 5 persons $(12.5 \%)$. This finding is similar to a study done by Alam et al., (2010), where most of their respondents who are farmers aged between 40 to 70 years, were predominantly males rather than female farmers. $40 \%$ of the respondents weighed between $61 \mathrm{~kg}$ to $70 \mathrm{~kg}$, followed by the weight group of $71 \mathrm{~kg}$ to $80 \mathrm{~kg}$ at $37.5 \%, 51 \mathrm{~kg}$ to $60 \mathrm{~kg}$ at $15 \%$, those who weigh below $50 \mathrm{~kg}$ at $5 \%$ and those who are above $80 \mathrm{~kg}$ at $2.5 \%$.

In another section of the questionnaire, the farmers were asked whether they are cultivating the paddy by themselves or with the help of hired workers. Based on the question, this study discovered that almost 29 (72.5\%) farmers were planting paddy on their own while 
the remaining 11 farmers (27.5\%) were working together with their hired workers. This was found to be similar to another study where the majority of farmers planted paddy by themselves (Pan and Siriwong, 2010). The farmers were also asked regarding duration that they have been using herbicide-containing imazapic. This is to assess their exposure duration with the imazapic compound. Through this question, it was found that more than half of the farmers involved in this survey $(67.5 \%)$ have been exposed to this compound for approximately three years. Meanwhile, $15 \%$ were exposed for two years, with only $5 \%$ for both one year and five years exposure. Additionally, $7.5 \%$ of farmers indicated no usage of imazapic at all, therefore, for the purpose of this study, they were considered as to have no direct exposure to the compound. None was recorded in the four years exposure category. Despite the fact that this herbicide containing imazapic had just been introduced in Malaysia, the fact that several of the respondents claimed usage of the compound for more than three years indicated that usage of this herbicide started before it was officially introduced. Therefore, the risk to these farmers could be higher.

The data received from respondents also covered their work duration based on days the respondents work on a weekly basis. Results showed that majority of the farmers $(65 \%)$ indicated that work involving activities in their paddy plot were carried out for five days a week. This is followed by the percentage of farmers worked four days a week at $17.5 \%$, six days a week at $7.5 \%$, three days a week at $5 \%$, and seven days of working also at $5 \%$. The results supported the findings from Pan and Siriwong (2010) where the majority of farmers worked for five days per week. As shown in the table, the questionnaire also comprises of farmers' exposure duration based on their working hour per day. Referring to the result shown, half of the respondents $(50 \%)$ carried out their work for two hours daily. As for those doing their work for three hours, the number of farmers who claimed this almost makes up the other half of the respondents at $42.5 \%$. This is followed by those carrying out their job for five hours per day at $5 \%$ and six hours per day at $2.5 \%$ which contrast with a similar study where most of its respondents spent around three hours per day in their paddy farming work (Pan and Siriwong, 2010).

Table 3: Characteristics of respondents.

\begin{tabular}{lcc}
\hline CHARACTERISTICS & NUMBER $(\mathbf{n}=40)$ & PERCENTAGE $(\%)$ \\
\hline GENDER & 35 & \\
Male & 5 & 87.5 \\
Female & & 12.5 \\
\hline AGE (years) & 8 & 20 \\
$<40$ & 7 & 17.5 \\
$41-50$ & 12 & 30 \\
$51-60$ & 12 & 30 \\
$61-70$ & 1 & 2.5 \\
$>70$ & & \\
\hline WEIGHT & 2 & 5 \\
$<50$ & 6 & 15 \\
$51-60$ & 16 & 40 \\
$61-70$ & 15 & 37.5 \\
$71-80$ & 1 & 2.5 \\
$>80$ & &
\end{tabular}




\begin{tabular}{|c|c|c|}
\hline \multicolumn{3}{|l|}{ PESTICIDE USED } \\
\hline OnDuty (containing imazapic) & 37 & 92.5 \\
\hline Not using OnDuty & 3 & 7.5 \\
\hline \multicolumn{3}{|l|}{ PLANTING METHOD } \\
\hline By themselves & 29 & 72.5 \\
\hline $\begin{array}{l}\text { By themselves and hired } \\
\text { worker }\end{array}$ & 11 & 27.5 \\
\hline \multicolumn{3}{|l|}{$\begin{array}{l}\text { EXPOSURE TO IMAZAPIC } \\
\text { (year(s)) }\end{array}$} \\
\hline None & 3 & 7.5 \\
\hline 1 & 2 & 5 \\
\hline 2 & 6 & 15 \\
\hline 3 & 27 & 67.5 \\
\hline 4 & 0 & 0 \\
\hline 5 & 2 & 5 \\
\hline \multicolumn{3}{|l|}{ WORKING DAYS } \\
\hline 3 & 2 & 5 \\
\hline 4 & 7 & 17.5 \\
\hline 5 & 26 & 65 \\
\hline 6 & 3 & 7.5 \\
\hline 7 & 2 & 5 \\
\hline \multicolumn{3}{|l|}{ WORKING HOURS PER DAY } \\
\hline 2 & 20 & 20 \\
\hline 3 & 17 & 17 \\
\hline 4 & 0 & 0 \\
\hline 5 & 2 & 5 \\
\hline 6 & 1 & 2.5 \\
\hline
\end{tabular}

\section{Dermal Exposure Assessment Analysis}

Figure 2 showed that one of the respondents have the highest value of absorbed dose per event with $0.22 \mathrm{mg} / \mathrm{cm}^{2}$-event.

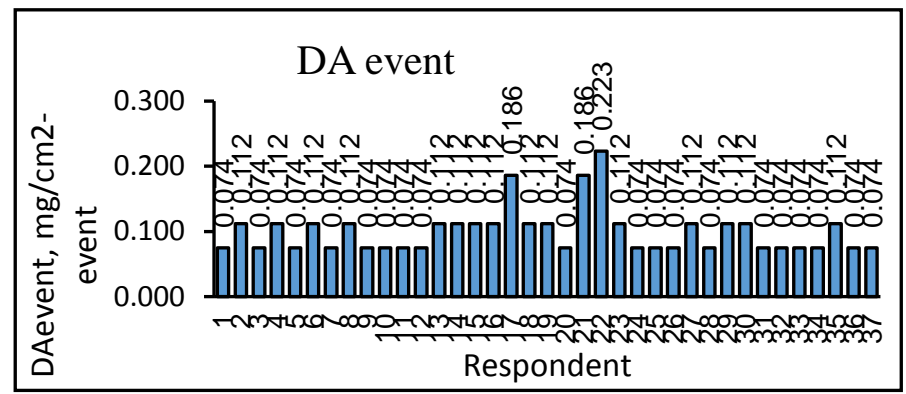

Figure 2: Absorbed dose per event for imazapic compound through dermal exposure.

The lowest DAevent was identified to be valued at $0.074 \mathrm{mg} / \mathrm{cm}^{2}$-event by most of the respondent $(51.35 \%)$. These values were then be used to calculate dermal absorbed dose before $\mathrm{HQ}$ could be determined. Once the $\mathrm{DAD}$ values were recognized, their acceptability 
is determined via comparison to the absorbed reference dose ( $\left.R f D_{A B S}\right)$, represented by the ratio that is known as $H Q$ where $H Q>1$ indicates at risk (Pan and Siriwong, 2010). $H Q$ for farmers exposure to pesticide containing imazapic were calculated for certain possible body surface based on their unsafe act of not wearing personal protective equipment (PPE) while handling pesticide. Unsafe acts include not wearing gloves and shoes. Body surfaces include the hands, arms, legs, and feet where the volume of these particular body surface were established in USEPA (2011) (Figure 3).

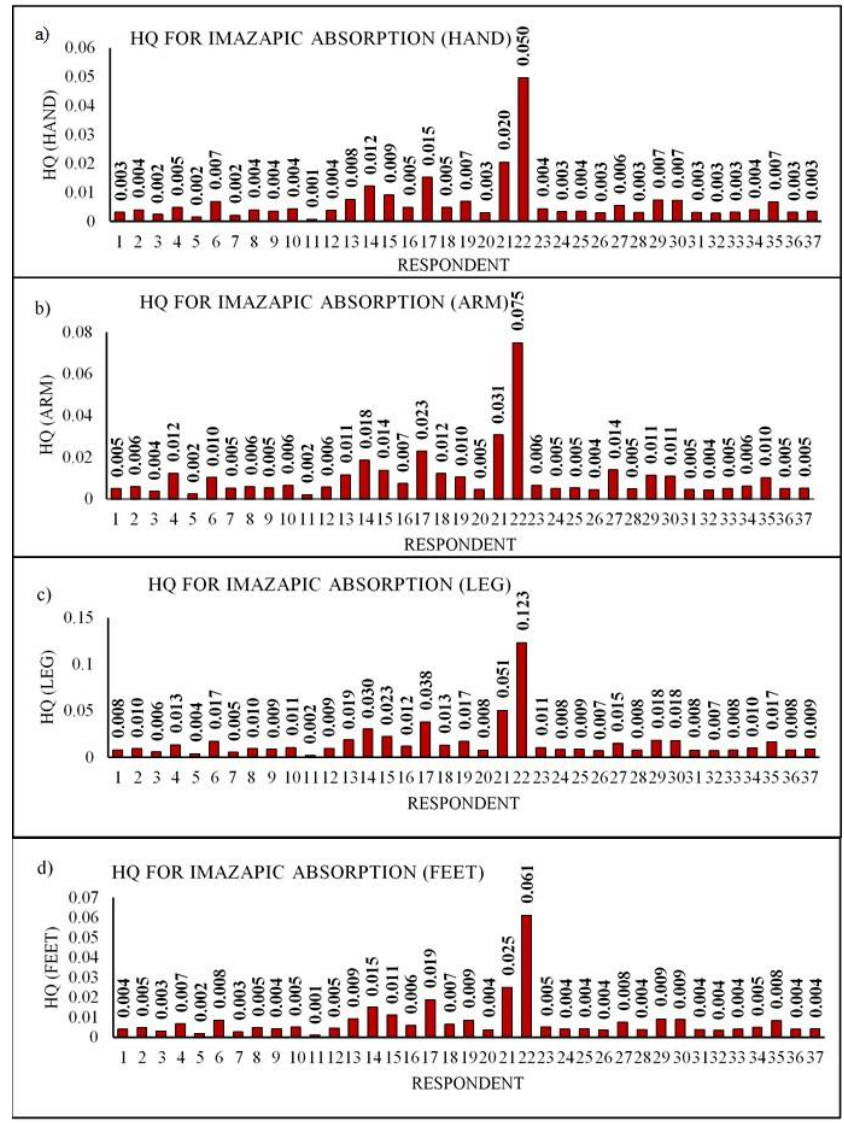

Figure 3: a) $H Q$ for imazapic concentration absorbed through hands; b) $H Q$ for imazapic concentration absorbed through arms; c) HQ for imazapic concentration absorbed through legs; d) $\mathrm{HQ}$ for imazapic concentration absorbed through feet.

Frequently, $\mathrm{HI}$ is used to determine the cumulative $\mathrm{HI}$ of several chemicals that would affect the same target organ via particular mode of action entering the body, but for this study $\mathrm{HI}$ is used to estimate the cumulative $\mathrm{HI}$ for imazapic compound through absorption via 
different body parts (hands, arms, legs, and feet) assuming that it will eventually affect the same target organ (Figure 4) (USEPA, 2012). Based on the results obtained, HI values for all of the respondents involved did not exceed the value of one, which indicate less hazard towards their health effects in relation to the usage of imazapic herbicide. However, there is the possibility of prolonged usage of this herbicide by farmers that could raise the risk towards them as mentioned by Snelder et al., (2008). In the study, Snelder et al., (2008) indicated that the slightly hazardous and moderately non-hazardous pesticide would still affect the farmers' health as well as the environment.

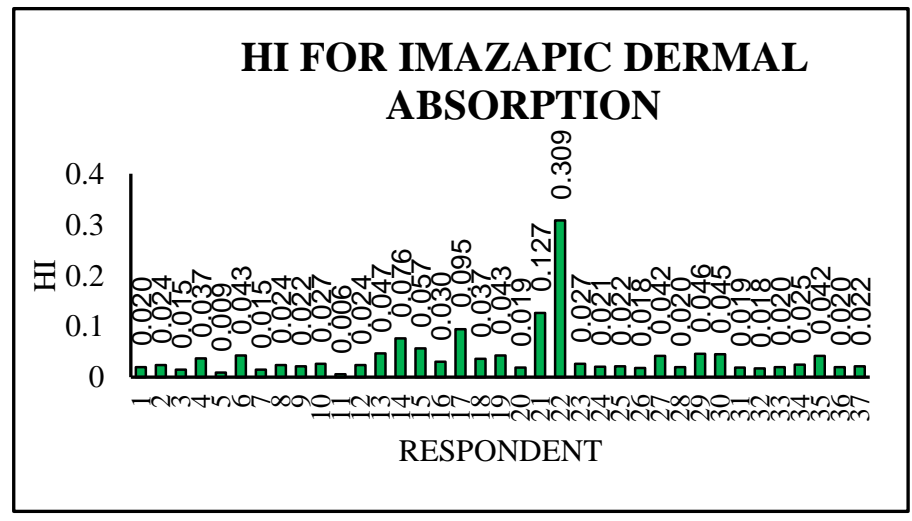

Figure 4: HI value estimated for cumulative absorption of the imazapic compound via hands, arms, legs, and feet.

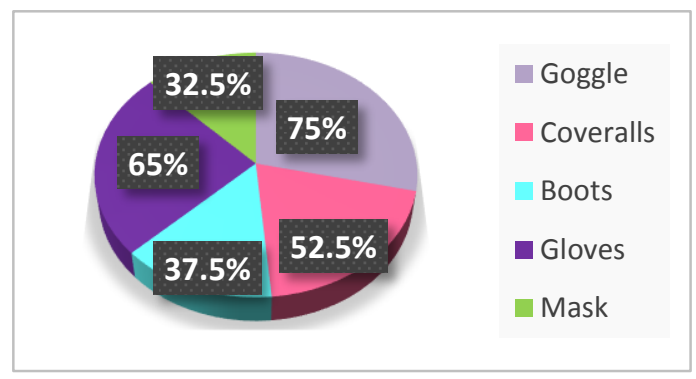

Figure 5: Percentage of personal protective equipment that are not worn by farmers during pesticide handling.

Additionally, observation on farmers' awareness on keeping a safe work practice indicated an area of major concern since most of the respondents were not wearing their PPE. Based on the chart shown, the highest percentage of PPE that were not consistently used are goggles at $75 \%$, followed by gloves at $65 \%$, coveralls at $52.5 \%$, boots at $37.5 \%$ and 
mask at $32.5 \%$ (Figure 5). The percentage showed that although the majority of the farmers, at least, wore a facemask during chemical handling, the PPE usage is highly inadequate. This could be due to their ignorance of the hazard for chemicals they are handling although some of them might already have the knowledge of good practice for pesticide spraying (Pan and Siriwong, 2010). According to Damalas and Eleftherohorinos (2011), regardless of any activity that are carried out which involves pesticides, there are potential occurrence of occupational exposure and it would increase further due to careless attitude towards instructions on safety use of the pesticide and also due to refusal to follow the guidelines of using PPE and vital sanitation practices; for example, washing their hands after pesticide application or before eating.

\subsection{Conclusion}

Since the HI calculated was lower than one; therefore, our result concluded that the risk level of farmers exposed to the pesticide containing imazapic compound is still low and posed a minimal amount of risk. However, since our results have also shown the inadequacy of PPE usage among the farmers, as well as the lack of knowledge regarding the subject, if left unmonitored, lack of PPE usage could one day lead to the risk of higher health hazard from imazapic exposure. Therefore, a different approach should be taken into account in order to ensure proper and adequate use of PPE amongst farmers.

During the course of the research, we encountered several limitations caused mainly by time constraint. Since we have specific time frame to carry out this research, we were unable to allocate enough time to make contact with farmers. As a result, our limited time frame did not allow us a large amount of time to actively pursue all the farmers which resulted in a low number of respondents whom are available during the time of research. A wider sample size of respondents would have given us a richer data to analyze especially in regards to the risk estimation of dermal exposure. While we stand by the results of this research, we propose that for future studies, more focus is needed on respondent interactions to obtain a wider sample size and richer data. Additionally, there is also a need for further study regarding the cumulative exposure from different pathways and types of pesticides applied on site. This is to identify which mechanism posed a higher risk that contributes towards farmers' health. Other than that, other factors should also be included in carrying out a risk assessment for estimating dermal exposure. This includes the rates of degradation for the assessed compound, cumulative risk value from the different types of pesticide being used at the same time and the protection factors provided from the use of protective clothing and equipment.

Apart from that, the level of awareness amongst the farmers can be improved using several efforts made both by the government and non-government bodies. For example, through conducting an integrated training on the proper pesticide management as well as conducting closed and frequent monitoring of pesticide handler especially farmers on their pesticide practice. This study will contribute towards the current limited body of knowledge regarding pesticide exposure among farmers in Malaysia. More effort should be made to promote a stronger policy and enforcement on pesticides safety requirements. Current 
licencing policy focus more on household usage of pest control, as such, other pesticide handlers such as farmers is disregarded. This will help to improve pesticide handler understanding and responsibility in order to reduce injury and severe health effects towards them.

\section{Acknowledgement}

The authors acknowledge the contribution of the Ethics committee of Faculty of Health Sciences, Universiti Teknologi MARA (UiTM). We are also grateful to the university for providing the necessary facilities to conduct the research and Faculty of Pharmacy, UiTM, Puncak Alam Campus for permitting the use of HPLC-UV instrument. Nevertheless, author's deepest gratitude is extended to the Ministry of Education, Malaysia and Universiti Teknologi MARA for the financial support for this research. This study was supported by Research Acculturation Grant Scheme (RAGS), Malaysia (no. 600-RMI/RAGS 5/3 (143/2014).

\section{References}

Alam, M. M., Siwar, C., Murad, M. W., Molla, R. I., \& Toriman, M. E. (2010). Socioeconomic Profile of Farmer in Malaysia: Study on Integrated Agricultural Development Area in North-West Selangor. Agricultural Economics and Rural Development New Series, 7(2), 249-265. Retrieved from ftp://www.ipe.ro/RePEc/iag/iag_pdf/AERD1013_249-265.pdf

Baumart, J. S. \& Santos, S. (2011). The Impact of Herbicides on Benthic Organisms in Flooded Rice Fields in Southern Brazil. In Dr Andreas Kortekamp (Ed.). Herbicides - Mechanisms and Mode of Action. (pp.369-382). Croatia: InTech Europe. Retrieved from: http://www.intechopen.com/books/herbicides-and-environment/the-impactof- herbicides-on-benthic-organisms-in-flooded-ricefields-in-southern-brazil.

Azmi M., Azlan, S.,Yim, K. M., George, T. V., \& Chew, S. E. (2012). Control Of Weedy Rice In Direct-Seeded Rice Using The Clearfield Production System In Malaysia. Pakistan Journal of Weed Science Research. 18(Special Issue):49-53.

Retrieved

from

https://www.researchgate.net/publication/265620716_CONTROL_OF_WEEDY_RICE_IN_DIRECT-

SEEDED_RICE_USING_THE_CLEARFIELD_PRODUCTION_SYSTEM_IN_MATLAYSIA

Caldas, S. S., Zanella, R., \& Primel, E. G. (2011). Herbicides and Environment: Risk Estimate of Water Contamination and Occurrence of Pesticides in the South of Brazil. In Dr Andreas Kortekamp (Ed.). Herbicides and Environment (pp. 471- 493). InTech Europe. Retrieved from: http://www.intechopen.com/books/herbicides-andenvironment/risk-estimate-of-water-contamination-and-occurrence-of-pesticide-in-the-south-of-brazil.

Colborn, T., \& Short, P. (1999). Pesticide Use In The U.S. And Policy Implications: A Focus On Herbicide. Toxicology and Industrial Health. 15:241-276.

Cox, C. 2003. Herbicide Factsheet. Journal of Pesticide Reform. 23(3):10-14.

Damalas, C. a., \& Eleftherohorinos, I. G. (2011). Pesticide exposure, safety issues, and risk assessment indicators. International Journal of Environmental Research and Public Health, 8(5): 1402-1419. http://doi.org/10.3390/ijerph8051402

Google Earth. (2015). V 7.1.5.1557. Kampung Sawah Sempadan, Tanjung Karang, Selangor Area, [maps], 
3०27'44.02"-3028'36.57" N; 101013'00.97"-101013'41.68" E, Eye alt 23.14 km. Retrieved from www.google.com/ earth/

Lesmes-Fabian, C., García-Santos, G., Leuenberger, F., Nuyttens, D., \& Binder, C. R. (2012). Dermal exposure assessment of pesticide use: The case of sprayers in potato farms in the Colombian highlands. Science of the Total Environment, 430, 202-208. http://doi.org/10.1016/j.scitotenv.2012.04.019

Mazlan, A. Z., Hussain, H., Zawawi, M. A. M., And Sameni, M. (2015). Analytical Method Development For Imazapic Herbicide Using High Performance Liquid Chromatography. 19(4):715-721. Retrieved from http://www.ukm.my/mjas/new_mjas/

Mohd Fuad M. J., Junaidi, A.B., Habibah, A., Hamzah, J., Toriman, M. E., Lyndon, N., Er, A.C., Selvadurai, S. and Aziman, A. M. (2012). The Impact Of Pesticides On Paddy Farmers And Ecosystem. Advances in Natural and Applied Sciences. 6(1):65-70.

Pan, U. M. \& Siriwong W. (2010). Risk Assessment for Dermal Exposure of Organophosphate Pesticide in Rice Growing Farmers at Rangsit Agricultural Area, Pathumthani Province, Central Thailand. Journal of Health Research, 24(2), 141-148. Retrieved from http://www.jhealthres.org/upload/journal/241/24\%28suppl2\%29_p141148_unmeipan.pdf

Sabere, A. S. M., Zakaria, Z. \& Ismail, B. S. (2013). Comparison of the Level of Organochlorine Residues in Paddy Crops from Two Different Cultivation Practices. Sains Malaysiana, 42(11), 1581-1584.

Snelder, D. J., Masipiquen, M. D., \& Snoo, G. R. De. (2008). Risk assessment of pesticide usage by smallholder farmers in the Cagayan Valley ( Philippines ), 27, 747-762. http://doi.org/10.1016/j.cropro.2007.10.011

Toriman, M. E., Yun, L. Q., Kamarudin, M. K. A., Aziz, N. A. A., Mokhtar, M., Elfithri, R., \& Bhaktikul, K. (2014). Applying seasonal climate trends to agricultural production in Tanjung Karang, Malaysia. American Journal of Agricultural and Biological Science, 9(1), 119-126. http://doi.org/10.3844/ajabssp.2014.119.126

United States Environmental Protection Agency. (2004). EPA: OSWER: Risk Assessment: "Supplemental Guidance for Dermal Risk Assessment", Part E of Risk Assessment Guidance for Superfund, Human Health Evaluation Manual (Volume I), August 16, 2004, (January 2000). Retrieved from http://epaprgs.ornl.gov/chemicals/help/documents/RAGS_E_EPA540R99005.pdf

United States Environmental Protection Agency. (2011). Exposure Factors Handbook: 2011 Edition. U.S. Environmental Protection Agency, EPA/600/R-(September), 1-1466. http://doi.org/EPA/600/R-090/052F

United States Environmental Protection Agency. (2012). Human Health Risk Assessment. Retrieved from http://www.epa.gov/risk_assessment/health-risk.htm

Yacob, A. N., Lee, T. L., \& Ibrahim, H. (2012). Conservetion, Consolidation and Economic Generation of Indigenous Community Agriculture Sustainable Food Yielding Reforestation. Procedia - Social and Behavioral Sciences, 68(November), 319-329. http://doi.org/10.1016/j.sbspro.2012.12.230

Zainudin, Z. (2010). Benchmarking river water quality in Malaysia. Jurutera. [Bulletin] (February):12-15. Retrieved from http://www.myiem.org.my/content/iem_bulletin_2010-185.aspx. 